\title{
Development of Problem Based Learning (Pbl)-Based E-Module to Improve Critical Thinking Skills of Students In Biology Learning Class $X$ Sman 1 Seberida Indragiri Hulu Regency
}

\author{
Nadia Sagita ${ }^{1}$, Yuni Ahda ${ }^{2}$, Syamsurizal ${ }^{3}$, Irdawati ${ }^{4}$ \\ ${ }^{1}$ Master Degree Program of Biology Education, Faculty of Mathematics and Sciences, Padang State University, Jl. Prof. Dr. West \\ Padang Freshwater Hamka - 25131 Indonesia \\ 2,3,4 Lecturer of Biology Department, Faculty of Mathematics and Sciences, Padang State University, Jl. Prof. Dr. West Freshwater \\ Hamka Padang-25131, Indonesia
}

\begin{abstract}
Critical thinking should be given to students as they age in the 21st century. The continued impact of perception shows that there are still many students who do not have the option to overcome their thinking, speaking, and logic skills. Observation results show that many students have not been able to utilize their intellectual ability to think critically. Furthermore, the evaluation questions that have been given by the teacher are not analytical in nature, resulting in not triggering students to think critically. Problem Based Learning (PBL) is a model of learning that is suitable for stimulating students' critical thinking. The purpose of this research that produces the E-module -based PBL valid, $p$ practical and $i$ effective. Type research is development research. The Plomp model is the applied model. The results of the study resulted in the level of validity of the PBL - based E-module which was $89.10 \%$ (very valid). The results of the practicality level of teachers are $94.17 \%$ (very practical) and the level of practicality by students is $86.47 \%$ (very practical). The results of the PBL - based E-module effectiveness test show that the PBL - based E-module is very effective. Thus, the conclusion is that the PBL - based E-module that has been developed is very valid, very practical, and very effective.
\end{abstract}

KEYWORDS: Problem based learning, e-module, critical thinking, development.

\section{INTRODUCTION}

Along with the times, science and innovation are also developing. The development of science and innovation is increasing day by day, both directly and by implication, giving a significant impact on several parts of human existence. One part of human existence that is influenced by advances in science and innovation is part of education.

Instruction plays an important role to work on the nature of HR. This is in accordance with learning in the 21st century, every ability needed by individuals so as not to face difficulties, everyday life that is increasingly confusing and full of vulnerabilities, and to survive in everyday life and professions in the realm. Work is a 21st century ability (Redhana, 2019).

In the 21st century, HR has begun to use innovation with the aim that today's people-driven capabilities no longer follow the guidelines of the past. The demands of science in the 21st century are to prepare students with different abilities and mastery such as imaginative, creative, assertive reasoning, and critical thinking (National Science Teachers Association, 2006).

The 2013 curriculum really requires 21st century skills, both in terms of content guidelines, process principles, and evaluation norms. One of the efforts to work on the nature of training is to complete various advances in educational programs, one of which is to include life teaching, especially basic skills, subtle abilities, and character education (Setyawati, 2013). In implementing the 2013 education plan, the ability to reason firmly is one of the abilities that must be driven by students.

According to Sudarma (2013) that in concept humans are God's creations who can make innovations and can think resulting in creating something imaginative, upheld by characters who can handle actual progress so that the ability to think critically becomes something vital to be raised in everyone. ., especially students.

One of them is the Biology learning process which is a logical and critical field of study, this is to expand efforts to encourage human reasoning. One of the goals of learning Biology is to show students how to think critically. Fisher (2009) defines that "critical thinking is reasonable and intelligent reasoning that focuses on choosing what to accept or do".

Mimbs (2005) revealed that the critical ability to help students is used as a significant ability in the present. Hasruddin (2009) explains that firm reasoning skills are very important for students to overcome problems and make choices according to logical truths. Students will better understand a material idea if the student's learning system is in a decisive reasoning ability.

Without the ability to think critically, people will often get data from various sources without remembering and choosing the data they get. Firm reasoning ability is very important to be developed because it will help in improving one's life after school (Wijayanti, et al., 2016). 


\section{Development of Problem Based Learning (Pbl)-Based E-Module to Improve Critical Thinking Skills of Students In Biology Learning Class X Sman 1 Seberida Indragiri Hulu Regency}

The results of the researchers' observations with the biology teacher of class X SMA Negeri 1 Seberida, namely Mr. Agus Purwikanto, S.Pd, the results showed that during the implementation of biology learning, educators were still carrying out conventional learning which resulted in weak critical thinking skills of students. The models that are often applied are lectures, discussions, and assignments so that the implementation of this learning has not been able to activate the interest that triggers criticism in students' thinking. In addition, the students' analytical skills, asking questions, and reasoning have not been maximized. The teacher during teaching has not trained students' critical skills and the questions presented by the teacher do not stimulate critical thinking. Because, during the learning process, the learning materials that are usually used to teach are in the form of textbooks and worksheets from schools. Teachers are known to have not used teaching materials in the form of emodules. In addition, students only absorb knowledge only from the teacher, as a result, students' critical thinking skills are classified as low.

Based on these problems, it is necessary to make efforts to stimulate students' critical thinking skills. The appropriate learning model to stimulate students' critical thinking skills is Problem Based Learning (PBL). According to Arends (2007) PBL can help students by developing critical thinking skills. The PBL model is a learning model that encourages critical thinking that is relied on to train students' decisive reasoning power.

The use of PBL can be supported by appropriate learning facilities and media, for example the use of electronic modules (emodules). Electronic modules (E-modules) are learning tools or facilities that contain materials, strategies, limits, and assessment techniques that are planned in an orderly and attractive manner to achieve normal skills which are indicated by the level of completeness electronically. The benefits of electronic modules compared to print modules are that they are intuitive, make routes simpler, empowering fast programmed criticism (Putri, et al 2015). Masek and Yamin (2010) revealed that emodules can be planned by referring to the structure of PBL stages.

The use of critical thinking focus e-modules can lead students to adapt freely and provide substantial involvement with critical thinking to prepare higher critical thinking skills including reasoning abilities that determine and assist students in constructing deductively correct ideas (Suarsana \& Mahayukti , 2013). The purpose of this research is to produce a PBL-based e-module to improve students' critical thinking skills in biology learning class X SMAN 1 Seberida that is valid, practical and effective.

\section{RESEARCH METHODS}

RESEARCH AND DEVELOPMENT IS THIS TYPE OF RESEARCH. ACCORDING TO TRIANTO (2010), DEVELOPMENT RESEARCH IS AN ARRANGEMENT OF CYCLES AND STEPS TO MAKE OTHER PRODUCTS OR FURTHER DEVELOP CURRENT PRODUCTS. THE RESEARCH BEING DEVELOPED IS PBL-BASED E-MODULE DEVELOPMENT. THE TEST SUBJECTS IN THE PBL - BASED E-MODULE DEVELOPMENT WERE STUDENTS OF CLASS X MIPA SMAN 1 SEBERIDA.

The development model used in the development of this PBL-based e-module is the Plomp model. In this research design, there is a formative evaluation at all stages and cycles. Plomp and Nieveen (2013) revealed several formative evaluation methods in development research designs which are illustrated in Figure 1.

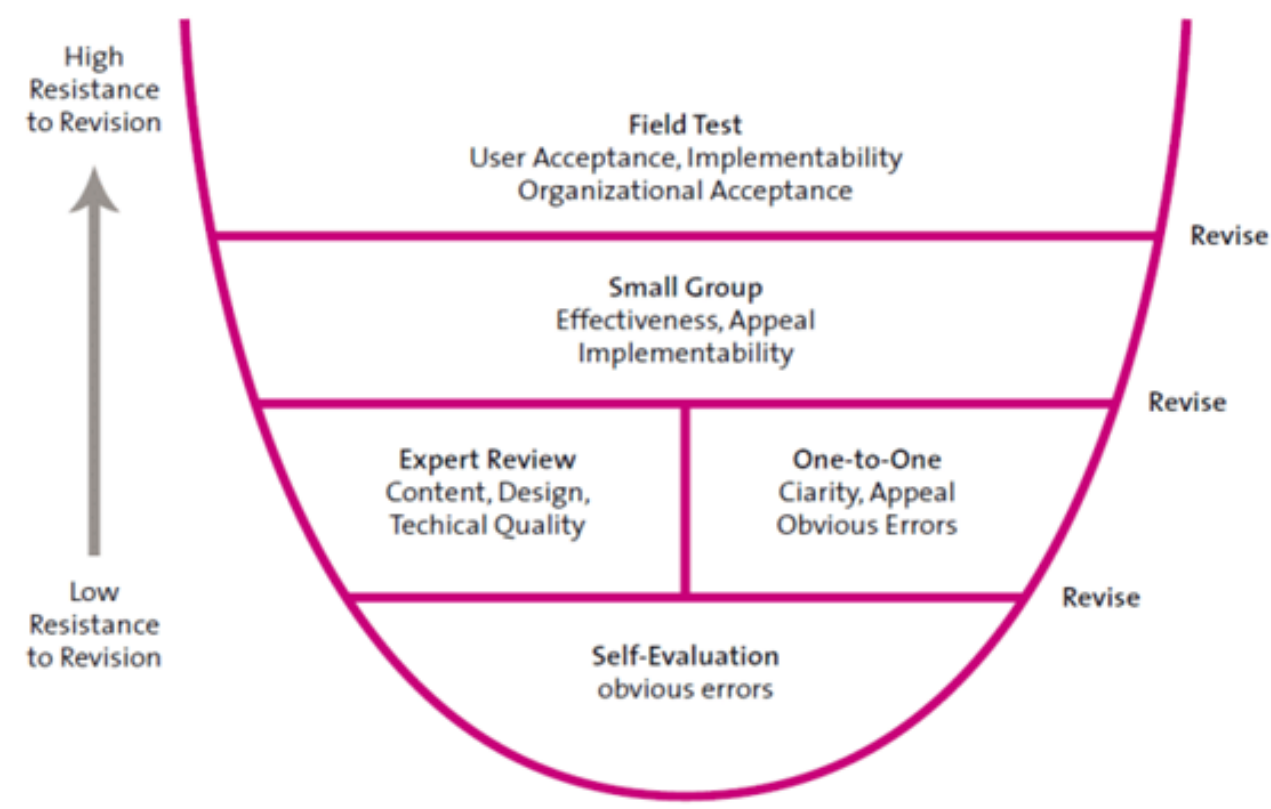

Figure 1. Formative Evaluation Layer

(Source: Plomp and Nieveen, 2013) 


\section{Development of Problem Based Learning (Pbl)-Based E-Module to Improve Critical Thinking Skills of Students In Biology Learning Class X Sman 1 Seberida Indragiri Hulu Regency}

Plom development consists of three stages. The stages of Plomp development can be seen in Table 2.

Table 2. Criteria and Description of Activities at the Plomp Development Stage.

\begin{tabular}{|l|l|l|}
\hline Stage & Criteria & $\begin{array}{l}\text { Description } \\
\text { Initial investigation }\end{array}$ \\
$\begin{array}{l}\text { validity than consistency and } \\
\text { practicality }\end{array}$ & $\begin{array}{l}\text { Locus on consistency } \\
\text { (construct validity) and } \\
\text { practicality ased as a guide in developing the product framework }\end{array}$ & $\begin{array}{l}\text { Development of a prototype sequence to be tried and } \\
\text { revised based on formative evaluation. Formative } \\
\text { evaluation is carried out through the assessment of experts } \\
\text { in order to produce the expected practicality }\end{array}$ \\
\hline Evaluation & Practicality and effectiveness & $\begin{array}{l}\text { Evaluate whether users can use the product (practicality) } \\
\text { and are willing to apply it in their teaching (relevance and } \\
\text { sustainability), as well as whether the product is effective. }\end{array}$ \\
\hline
\end{tabular}

(Source: Plomp and Nieveen, 2013)

The last stage is the assessment phase (assessment phase). At this stage of the assessment, a semi-summative evaluation is carried out which aims to determine the effectiveness of the products that have been produced in the second stage, namely the development or manufacture of prototypes.

\section{RESULTS AND DISCUSSION}

A. Validity The validation process is carried out at the prototype stage II. The e-module validation was carried out by three experts. These three experts are material experts, language experts, and language experts. Aspects assessed in the validity questionnaire are didactic, construct and technical. The didactic aspect includes the suitability of the e-module which was developed with the 2013 revised 2017 curriculum and based on the learning needs of students. Aspects of the construct assessed for the suitability of the developed e-module with the criteria that must be met in the development of the e-module, the suitability of the PBL stages developed, and the rules for using the Indonesian language. The technical aspects assessed are the suitability of writing, images, and graphics in the developed e-module. The results of product validation by experts can be reviewed in Table 2.

Table 2. Results of Data Analysis Validation of Three Validators

\begin{tabular}{|l|l|l|l|}
\hline No. & Assessment Aspect & Score (\%) & Category \\
\hline 1. & Didactic & $88.33 \%$ & Very Valid \\
\hline 2. & Construct & $92.86 \%$ & Very Valid \\
\hline 3. & Technical & $86.11 \%$ & Very Valid \\
\hline Average Validity Value & $\mathbf{8 9 . 1 0 \%}$ & Very Valid \\
\hline
\end{tabular}

The results of the validity of Table 2 show that the requirements to meet the criteria for the validity of the e-module have been met. This is because the level of validation of the e-module that has been developed is categorized as very valid, namely 89.10\%. Valid e-modules can be tested for the next stage.

\section{B. Practicality}

Practicality is carried out at the assessment stage. However, the e-module must first be evaluated for its practicality before it is ready to be tested during the research process (assessment stage). Evaluation of the practicality of the e-module using small group evaluation at the third prototype stage. The results of the evaluation of small groups can be seen in table 3.

Table 3. Small Group Evaluation Results

\begin{tabular}{|l|l|l|l|}
\hline No. & Value Aspect & $\mathbf{( \% )}$ & Criteria \\
\hline 1. & Ease of Use & $81.25 \%$ & Very practical \\
\hline 2. & Efficiency & $85.42 \%$ & Very practical \\
\hline 3. & Attractiveness & $81.25 \%$ & Very practical \\
\hline 4. & Easy to interpret & $83.33 \%$ & Very practical \\
\hline 5. & Have Equivalence & $85.42 \%$ & Very practical \\
\hline \multicolumn{2}{|l|}{ Average Practicality Score } & $\mathbf{8 3 . 3 3}$ & Very practical \\
\hline
\end{tabular}

The evaluation results in Table 3 show that the PBL-based e-module on biodiversity and virus materials developed has a practical value of $83.33 \%$ with very practical criteria. The criteria for the e-module include aspects of ease of use, efficiency, attractiveness, ease of interpretation and equivalence.

PBL-based e-modules that have been evaluated for practicality are carried out practicality tests at the assessment stage when research uses a filed test. The practicality of the e-module at the time of the filed test was assessed by teachers and 


\section{Development of Problem Based Learning (Pbl)-Based E-Module to Improve Critical Thinking Skills of Students In Biology Learning Class X Sman 1 Seberida Indragiri Hulu Regency}

students. The practicality of the e-module is assessed by a Biology teacher who teaches in class X MIPA in the odd semester of 2020/2021. The results of practicality by teachers can be reviewed in Table 4.

Table 4. Practicality Assessment by Teachers

\begin{tabular}{|l|l|l|l|}
\hline No. & Value Aspect & $\mathbf{( \% )}$ & Criteria \\
\hline 1. & Ease of Use & $91.67 \%$ & Very practical \\
\hline 2. & Efficiency & $100 \%$ & Very practical \\
\hline 3. & Attractiveness & $91.67 \%$ & Very practical \\
\hline 4. & Easy to interpret & $87.50 \%$ & Very practical \\
\hline 5. & Have Equivalence & $100 \%$ & Very practical \\
\hline Average Practicality Score & $94.17 \%$ & Very practical \\
\hline
\end{tabular}

The results of the assessment in Table 4 show that the PBL-based e-module obtained an average score of $94.17 \%$. The e-module that has been developed has received a very practical assessment by the teacher. Meanwhile, the practicality assessment by students was tested in the experimental class. The results of the assessment can be reviewed in Table 5.

Table 5. Student Practical Results.

\begin{tabular}{|l|l|l|l|}
\hline No. & Value Aspect & $\mathbf{( \% )}$ & Criteria \\
\hline 1. & Ease of Use & $87.64 \%$ & Very practical \\
\hline 2. & Efficiency & $85.42 \%$ & Very practical \\
\hline 3. & Attractiveness & $84.17 \%$ & Very practical \\
\hline 4. & Easy to interpret & $86.39 \%$ & Very practical \\
\hline 5. & Have Equivalence & $88.75 \%$ & Very practical \\
\hline \multicolumn{2}{|l|}{ Average Practicality Score } & $\mathbf{8 6 . 4 7 \%}$ & Very practical \\
\hline
\end{tabular}

The results of the assessment in Table 5 show that the PBL-based e-module obtained an average score of $86.47 \%$. The e-module that has been developed has received a very practical assessment by students. The assessment by students was carried out by 30 students in the experimental class. From the practical assessment at the time of the filed test conducted by the teachers and students, it shows that the e-module that has been developed has received a very practical assessment. According to Sukardi (2012), practicality can be seen from the implementation time which should be short, fast and precise.

\section{Effectiveness}

The effectiveness test is assessed from student learning outcomes. Learning outcomes are seen through critical thinking skills. The assessment was carried out in the experimental class and the control class. The class that was treated using the e-module product was the experimental class, while the control class used teaching materials commonly used by teachers.

The test given is an essay question. The same questions were given to the control and experimental classes. The results of the assessment of students' critical thinking skills through essay questions can be reviewed in Table 6 .

Table 6. Assessment of Students' Critical Thinking Skills Results

\begin{tabular}{|l|l|l|l|l|l|}
\hline Class & N & Xmin & Xmax & mean & Standard deviation \\
\hline Experiment & 30 & 64 & 94 & 78.07 & 7.638 \\
\hline Control & 30 & 50 & 80 & 63.67 & 7.411 \\
\hline
\end{tabular}

The results of the assessment of students' critical thinking skills in Table 5, the average value of the experimental class was 78.07 and the control class was 63.67. That is, the control class obtained a lower average value than the experimental class. The experimental class is a class that is given treatment in the form of a PBL - based e-module on biodiversity and viruses, while the control class is a class without treatment. Furthermore, these results were analyzed by data to test the hypothesis. Hypothesis testing is carried out by prerequisite tests first. Prerequisite tests are normality and homogeneity tests. The results of normality and homogeneity tests can be reviewed in Table 7.

Table 7. Prerequisite Test Results for Normality and Homogeneity of Critical Thinking S

\begin{tabular}{|l|l|l|l|}
\hline No. & Parameter & Significance & Information \\
\hline 1. & Normality & 0.200 & Normal \\
\hline 2. & Homogeneity & 0.744 & Homogeneous \\
\hline
\end{tabular}

The results of the normality test showed a significance of 0.200 . This result shows a significance value greater than 0.05 . That is, the value of critical thinking skills is normally distributed. Furthermore, the results of the homogeneity test showed a significance of 0.744 . This result shows a significance value greater than 0.05 . That is, the value of students' critical thinking skills is homogeneous. After the prerequisite test, the results are normal and homogeneous, meaning that the hypothesis test is 


\section{Development of Problem Based Learning (Pbl)-Based E-Module to Improve Critical Thinking Skills of Students In Biology Learning Class X Sman 1 Seberida Indragiri Hulu Regency}

carried out using the $t$ test. The results of hypothesis testing of critical thinking skills in the experimental and control classes can be reviewed in Table 8.

Table 8. Calculation Results of t-test of Critical Thinking Skills

\begin{tabular}{|l|l|l|}
\hline Class & Significance & Conclusion \\
\cline { 1 - 2 } Control & 0.000 & $\mathrm{H}_{0}$ rejected \\
\hline
\end{tabular}

The results of the t-test calculation show a significance of 0.000 . This result shows a significance value less than 0.05 . That is, $\mathrm{H}_{0}$ is rejected and $\mathrm{H}_{1}$ accepted. Thus, it is known that the use of PBL - based e-Module on biodiversity and virus material affects the critical thinking skills of the tenth graders of SMAN 1 Seberida.

According to Gorghiu (2015), PBL that utilizes issues in fact affects students' assertive reasoning. In line with Hosnan (2014), which states that the main purpose of PBL is to cultivate students' assertive reasoning abilities, critical thinking skills and build their own insights. The PBL model can produce decisive reasoning abilities and valuable new information for as long as possible (Sungur and Caren, 2006).

\section{CONCLUSION}

Research and development

A. The validation results by the validators show that the e-module based on Problem Based Learning (PBL) on biodiversity and virus materials has very valid criteria.

$B$. The results of practical tests conducted by teachers and students show that the e-module based on Problem Based Learning $(\mathrm{PBL})$ on biodiversity and virus materials has very practical criteria.

$C$. The results of the effectiveness test of the use of Problem Based Learning (PBL) -based e-modules on biodiversity and virus materials have effective criteria on critical thinking skills.

\section{REFERENCES}

1) Arends, R. I. (2008). Learning to Teach: Belajar untuk Mengajar. Yogyakarta: Pustaka Pelajar.

2) Fisher, A. (2009). Berpikir Kritis Sebuah Pengantar. Jakarta: Erlangga, 4.

3) Gorghiu, G. (2015). Problem-Based Learning-An Effecient Learning Strategy In The Science Leassons Context. ProcediaSocial and Behavioral Sciences 191 (2015) 1865-1870.

4) Hasruddin. (2009). Memaksimalkan Kemampuan Berfikir Kritis Melalui Pendekatan Kontekstual. Journal Tabularasa PPS Unimed, 6 (1): 48-60.

5) Hosnan, M. (2014). Pendekatan Saintifik dan Kontekstual dalam Pembelajaran Abad 21. Bogor: Ghalia Indonesia.

6) Masek, A \& Yamin, S. (2010a). Problem Based Learning: A Collection from the Literature. Journal of Asian Social Science, 6(8): 148-158.

7) Mimbs, C.A. (2005). Teaching from the Critical Thinking, Problem-Based Curricular Approach: Strategies, Challenges, and Recommendations. Journal of Family and Consumer Sciences Education. Vol. 23 (2).

8) Plomp, T and Nieveen, N. (2013). Education Design Reserch: An Introduction. Enshede: SLO. Netherlands Institute for Curriculum Develompment.

9) Redhana, I. W. (2019). Mengembangkan keterampilan abad ke-21 dalam pembelajaran kimia. Jurnal Inovasi Pendidikan Kimia, 13(1).

10) Setyawati, R.D. (2013). “Pengembangan Perangkat Pembelajaran Matematika Model Problem Based Learning Berorientasi Enterpreneurship dan Berbantuan CD Interaktif". Prosiding Seminar Nasional Matematika 2013. Semarang: Universitas Negeri Semarang.

11) Suarsana, M. \& Mahayukti, A. (2013). Pengembangan e-modul berorientasi pemecahan masalah untuk meningkatkan keterampilan berpikir kritis mahasiswa. JPI (Jurnal Pendidikan Indonesia), 2(2).

12) Sudarma, Momon. (2013). Mengembangkan Keterampilan Berpikir Kreatif. Jakarta: Raja Grafindo Persada.

13) Sukardi. (2011). Metodologi Penelitian Pendidikan, Kompetensi dan Praktiknya. Jakarta: PT Bumi Aksara.

14) Sungur, S., Ceren, T. 2006. Effect of Problem Based Learning and Traditional Instruction on Self-Regulated Learning. The Journal of Educational Research. Vol. 99 (5).

15) Wijayanti, T. F., Prayitno, B. A., \& Sunarto, S. (2016). Pengembangan Modul Berbasis Berpikir Kritis Disertai Argument Mapping pada Materi Sistem Pernapasan untuk Meningkatkan Kemampuan Berpikir Kritis Siswa Kelas XI SMA Negeri 5 Surakarta. Inkuiri, 5(1), 105-111. 